\section{Lipid Levels of Young Individ- uals Who Were Admitted To the Hospital}

Zeynep Hülya Durmaz ${ }^{*}$, Aslıhan Dilara Demir ${ }^{2}$, Cetin KIInc ${ }^{3}$ Rıdvan Güçkan ${ }^{4}$ and Meral Tiryaki ${ }^{5}$

${ }^{1}$ Department of Biochemistry, Amasya University Research Hospital, Amasya, Turkey

${ }^{2}$ Department of Internal Medicine, Amasya University Research Hospital, Amasya, Turkey

${ }^{3}$ Department of Microbiology, Amasya University Research Hospital, Amasya, Turkey

${ }^{4}$ Department of Microbiology, Amasya University Research Hospital, Amasya, Turkey

${ }^{5}$ Department of Pathology, Dışkapı Yıldırım Beyazıt Education and Research Hospital, Ankara

\section{Abstract \\ Aim \\ In this study total cholesterol, triglyceride, LDL and HDL levels were evaluated in blood of individuals referred to Research Hospital Polyclinic of the Amasya University Training and Research Hospital. Materials and Methods \\ 500 patients, comprised of 166 male and 334 female was includ- ed to this study. Results are evaluated statisticially. \\ Conclusion \\ Mean cholesterol levels of individuals were determined $174.83 \pm 38.92 \mathrm{mg} / \mathrm{dl}$ in males and $165.82 \pm 32.29 \mathrm{mg} / \mathrm{dl}$ in females. Male patient's mean triglyceride levels is $135.68 \pm 78.33 \mathrm{mg} / \mathrm{dl}$, female patient's triglyceride level was $102.72 \pm 60.39 \mathrm{mg} / \mathrm{dl}$. Male patient's mean HDL level was $46.67 \pm 9.22 \mathrm{mg} / \mathrm{dl}$, female patient's trigliserid level was $58.33 \pm 15.33 \mathrm{mg} / \mathrm{dl}$. Male patient's mean LDL level was $120.7 \pm 35.42 \mathrm{mg} / \mathrm{dl}$, female patient's LDL level was $108.49 \pm 30.33$ $\mathrm{mg} / \mathrm{dl}$. \\ Findings \\ Although the individuals who have included this study were young, total Cholesterol, triglyceride and LDL levels were deter- mined above optimal value. This situation makes us think that car-}

*Corresponding author: Zeynep Hülya Durmaz, Department of Biochemistry, Amasya University Research Hospital, Amasya, Turkey, Tel: +90 3582184000 Extn: 1492; E-mail: aakdenizhulyaa2141@gmail.com

Citation: Durmaz HZ, Demir DA, Kılınç C, Güçkan R, Tiryaki M (2017) Lipid Levels of Young Individuals Who Were Admitted To the Hospital. J Diabetes Metab Disord 4: 021.

Received: March 07, 2017; Accepted: September 13, 2017; Published: September 27, 2017

Copyright: @ 2017 Durmaz HZ, et al., This is an open-access article distributed under the terms of the Creative Commons Attribution License, which permits unrestricted use, distribution, and reproduction in any medium, provided the original author and source are credited. diovascular risk may develop in forward years. This situation is more important in males.

Keywords: HDL; Hyperlipidemia; LDL

\section{Introduction}

Lipids have important functions in organisms. They are involved in the cell membrane structure [1]. Cholesterol is the precursor molecule of steroid hormones and bile acids. The body gets the cholesterol by diet or it is synthesized primarily by liver cells. Lipids are transported by binding to Apoproteins (Apo) which have a hydrophilic structure and they form lipoproteins. Lipoproteins are separated into chylomicrons, Very Low Density Lipoproteins (LDL), Intermediate Density Lipoproteins (IDL), Low Density Lipoproteins (LDL), High Density Lipoproteins (HDL), and Lipoprotein A (Lp A) in electrophoresis. Main part of the cholesterol is transported by LDL, endogenous triglycerides, and VLDL. Cholesterol is transported by HDL from peripheral tissues to the liver [2]. Hyperlipidemia is characterized with the increase in circulating blood fats [3]. Hyperlipidemia is observed as the primary disorder of the lipid metabolism. It can also be formed due to the secondary deteriorations. Primary disorders are hypercholesterolemia, hyper triglyceridemia or the combination of hypercholesterolemia and hyper triglyceridemia and low levels of HDL levels. Secondary deteriorations are nephrotic syndrome, diabetes, hypothyroidism, chronic liver disease, alcoholism and the long-term use of some drugs [2]. The normal levels of these lipid parameters are presented in table 1 .

In the world as well as in our country, atherosclerosis and its complications are the most important reasons for deaths. Atherosclerosis is a chronic inflammatory disease which is characterized with endothelial dysfunction and dyslipidemia. Inflammatory cells have a central role and various factors can lead to atherosclerosis. Endothelial dysfunction has an important function in the development of atherosclerosis. LDL passes through the vascular endothelial tissue. This leads to the secretion of various cytokines. Inflammatory cells start to accumulate in the intima. Macrophages engulf the oxidized LDL in the intima. Foam cells are formed and yellow streaks start to underlie under the intima. This is the first lesion of the atherosclerosis. Necrotic lipid core is formed as a result of the apoptosis of the foam cells. Smooth muscle cells proliferate in the intima around the lipid core. Fibrous plaque, which narrows the lumen, is formed. Plague capsule is ruptured and then it can lead to fibrous plaque [4]. Atherosclerotic Coronary Artery Disease is a disease of the vessel wall [5]. Symptoms of the Coronary Artery Disease (CAD) are formed because of the difference between the regional blood flows [6]. The aim of this study was to detect the levels of serum total cholesterol, triglycerides, LDL, HDL in healthy individuals and to call the attention to the related risk factors.

\section{Materials and Methods}

In this study, the patient database of the hospital was obtained between July and December 2014. 166 male and 334 female; total 500 patients were included in the study. Patients who had a liver disease, 
kidney disease, diabetes, and thyroid dysfunction were excluded from the study. Serum total cholesterol, triglyceride, LDL, HDL levels were tested by using Roche cobas 8000 device. Total cholesterol was determined by using enzymatic and colorimetric methods. HDL and LDL levels were tested by using homogenous colorimetric enzyme method. Triglyceride levels were determined by using a colorimetric method.

\section{Data Analysis}

Data of the study were evaluated by using SPSS 21.0 statistical program. Categorical data were represented as number and percentage. Numeric data were represented as mean and standard deviation. Kolmogorov-Smirnov test was used to test whether or not the data of the study were normally distributed. The differences between male and female were tested by using Students-t test. The level of statistical significance was accepted as $0.05(\mathrm{p}<0.05)$.

\section{Results}

The Mean \pm SD of Total cholesterol, triglycerides, HDL and LDL levels according to the age and gender is presented in (Table 2).

When the mean age of the participants were evaluated according to their gender, it was found that there was no significant difference $(\mathrm{p}=0.18)$. The mean cholesterol levels of male patients were $174.83 \pm 38.92 \mathrm{mg} / \mathrm{dl}$ and the female was $165.82 \pm 32.29 \mathrm{mg} / \mathrm{dl}$. The difference between cholesterol levels of male and female individuals were statistically significant $(\mathrm{p}=0.01)$. The mean cholesterol levels were significantly $(\mathrm{p}<0.01)$ higher in male patients than female ones. The mean triglyceride level of male patients was $135.68 \pm 78.33 \mathrm{mg} / \mathrm{dl}$ and the mean triglyceride level of female patients was $102.72 \pm 60.39$ $\mathrm{mg} / \mathrm{dl}$. The average triglyceride levels were significantly $(\mathrm{p}<0,001)$ higher in males as compared to females. The mean HDL level of male patients was $46.67 \pm 9.22 \mathrm{mg} / \mathrm{dl}$ and the mean HDL level of female patients was $58.33 \pm 15.33 \mathrm{mg} / \mathrm{dl}$. The difference between HDL levels of male and female patients was statistically significant $(\mathrm{p}<0.001)$. The mean LDL level of male patients was $120.17 \pm 35.42 \mathrm{mg} / \mathrm{dl}$ and the mean LDL level of female being higher in females than males was $108.49 \pm 30.33 \mathrm{mg} / \mathrm{dl}$. Average HDL levels were significantly $(\mathrm{p}<0.001)$ higher in females when compared to male ones and average LDL levels were significantly $(\mathrm{p}<0.001)$ higher in male patients as compared to female patients (Table 3 and Figures 1-5).

\section{Discussion}

Hyperlipidemia can lead to atherosclerosis and CAD that is the most important health issue in the world [7,8]. Atherosclerosis plays an important role in the pathogenesis of the CAD [9]. Hyperlipidemia is the primary factor for heart disease and stroke [10]. Most common lipoproteins are LDL and HDL. LDL cholesterol circulates 2.5 days in the body. Then it binds to LDL receptors of liver cells and is digested. Cholesterol synthesis is suppressed by HGMCOA (3-hidroksi-3- metil-glutaril-KoA) reductase [11]. LDL receptor functions are either decreased or absent in familial hyperlipidemia. Therefore, LDL circulates 4.5 days in the body [12]. In a study in Adana, 494 patients older than 20 years were examined. It was found that lipid levels of these patients were higher than the levels which were previously found in epidemiological studies [13]. According to the findings of heart disease and risk factors in Turkish adults study, the mean of total cholesterol level was $185 \mathrm{mg} / \mathrm{dl}$, the mean LDL level was 116 $\mathrm{mg} / \mathrm{dl}$, the mean triglyceride level was $143 \mathrm{mg} / \mathrm{dl}$, and the mean HDL level was $37 \mathrm{mg} / \mathrm{dl}$ in male and $45 \mathrm{mg} / \mathrm{dl}$ in female. In this study, LDL levels of male and female individuals were the same. The two units increase in the total cholesterol/HDL rate increased the non-fatal and fatal cardiovascular disease risk as $68 \%$. It was observed that majority of adults had $180-200 \mathrm{mg} / \mathrm{dl}$ total cholesterol levels. It is recommended to decrease the total cholesterol to $180 \mathrm{mg} / \mathrm{dl}$ in men [14].

In a study in Tokat, 1095 individuals were examined. Total cholesterol and LDL cholesterol levels were normal, HDL cholesterol levels were low. The prevalence of dyslipidemia was found to be high [15]. In a study that was conducted with 71 patients who were admitted to the emergency unit of the hospital with the chest pain, lipid profile deteriorations were accepted as one of the main risk factors for coronary heart diseases. However, lipid profile changes were not accepted as the risk factors for the acute coronary syndromes. It is believed that changing the life style of individuals can decrease the total risk load [16]. In another study, 10 years of cardiovascular disease risks of 72 patients were calculated. Smoking, hypertension, and hyperlipidemia were found as most important risk factors for cardiovascular diseases [17]. Apo E $\varepsilon 4$ allele and oxidized LDL levels of 12 control individuals and 49 patients who were diagnosed with myocardial infarction were examined in another study. According to the findings, Apo E $\varepsilon 4$ allele and oxidized LDL levels affect the formation of atherosclerosis [18]. In a study in Japan, a positive relationship was detected between increased cholesterol levels, coronary stenotic coronary index, and high blood pressure [19]. Another study showed that there is a correlation between the coronary artery disease and LDL levels. Totally 1.5 million Americans experience a myocardial infarction each year. One third of them cannot survive. In a newly updated NCEP guidelines, it is reported that majority of the patients are the candidates for the hyperlipidemic treatment. The number of patients who received a diet therapy in the United States of America increased from 52 million to 62 million. The number of patients who receive a drug therapy increased from 13 million to 36 million. Framingham still continues the study in which they have been following patients for 40 years. It is observed that $85 \%$ of the patients with cholesterol levels lower than 180 for 30 years survived. Patients with cholesterol levels greater than $260 \mathrm{dl}$ died [3].

According to various epidemiological studies, low HDL cholesterol level is a major and independent factor in the development of acute coronary events. It is shown in a study that each $1 \mathrm{mg} / \mathrm{dl}$ increase in the HDL level decreases the CAD risk by $2-3 \%$ [20]. Hyperlipidemia should be rapidly treated when acute pancreatitis is concomitantly observed. The priorities of the hyperlipidemia treatment are smoking cessation, proper nutrition, and exercise. American Diabetes Association recommends a strict hyperlipidemia treatment in diabetes patients in order to decrease the CAD risk [7]. Most simple and effective way is to protect the ideal weight, perform a regular exercise, decrease smoking, having a proper nutrition, and check the early and periodical blood pressure levels. It can be possible to determine individuals at risk by taking these precautions from childhood [21]. American Academy of Pediatrics suggests analyzing the lipid levels of individuals who have family members with hypercholesterolemia or early CAD [22]. There are different approaches in order to determine individuals at high risk; for instance community screening or screening with selected cases. However, the method should be cheap and its effectiveness should be high in order to achieve the community screenings [19]. Hyper cholesterolemiais one of the primary factors for coronary atherosclerosis and its treatment decreases the mortality and the atherosclerotic heart disease risk in older ages [22]. 
Citation: Durmaz HZ, Demir DA, Kllnç C, Güçkan R, Tiryaki M (2017) Lipid Levels of Young Individuals Who Were Admitted To the Hospital. J Diabetes Metab Disord 4: 021 .

- Page 3 of $4 \cdot$

\begin{tabular}{|c|c|c|c|c|}
\hline & Optimal & Normal & $\begin{array}{c}\text { High and at the Upper Level of the } \\
\text { Reference Range }\end{array}$ & High \\
\hline Total Cholesterol (TC) & & $\mathrm{mg} / \mathrm{dl} 200>$ & $\mathrm{mg} / \mathrm{dl} 200-239$ & $\mathrm{mg} / \mathrm{dl} 240<$ \\
\hline LDL-C & $\mathrm{mg} / \mathrm{dl} 100>$ & $\mathrm{mg} / \mathrm{dl} 130>$ & $\mathrm{mg} / \mathrm{dl} 130-159$ & $\mathrm{mg} / \mathrm{dl} 160<$ \\
\hline \multirow{2}{*}{ HDL-C } & & Male $>40 \mathrm{mg} / \mathrm{dl}$ & & $\mathrm{mg} / \mathrm{dl} 60<$ \\
\hline Triglyceride & & Female $>50 \mathrm{mg} / \mathrm{dl}$ & & $\mathrm{mg} / \mathrm{dl} 200<$ \\
\hline
\end{tabular}

Table 1: The normal levels of these lipid parameters can be seen in the classification of ATP III lipid parameters.

\begin{tabular}{|c|c|c|c|c|c|}
\hline Feature & Male & Female & Total & T \\
\hline Age & $29.76 \pm 6.66$ & $28.89 \pm 7.06$ & $29.18 \pm 6.94$ & 1.316 \\
\hline Total Cholesterol & $174.83 \pm 38.92$ & $165.82 \pm 32.29$ & $168.82 \pm 34.85$ & 2.574 \\
\hline Triglycerides & $135.68 \pm 78.33$ & $102.72 \pm 60.39$ & $113.67 \pm 68.58$ & 0.18 \\
\hline HDL & $46.67 \pm 9.22$ & $58.33 \pm 15.33$ & $54.46 \pm 14.67$ & 0.01 \\
\hline LDL & $120.17 \pm 35.42$ & $108.49 \pm 30.33$ & $112.37 \pm 32.54$ & $3.001>$ & 3.637 \\
\hline
\end{tabular}

Table 2: Mean \pm SD of total cholesterol, triglycerides, HDL and LDL levels according to the age and gender.

$\mathrm{p}$ value $<0.05$ means significant difference between male and female individuals

\begin{tabular}{|c|c|c|}
\hline Gender & Number & Percentage \\
\hline Male & 166 & 33.2 \\
\hline Female & 334 & 66.8 \\
\hline Total & 500 & 100.0 \\
\hline
\end{tabular}

Table 3: The number and percentage of the study group.

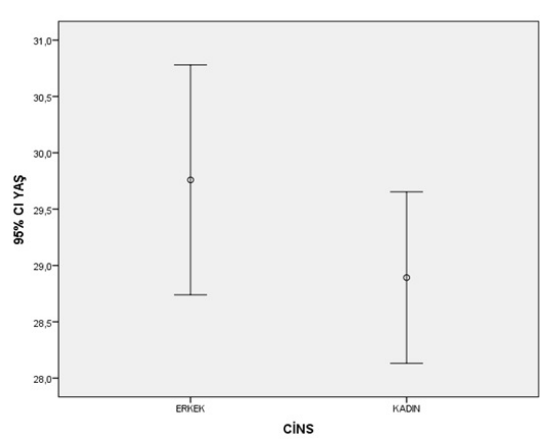

Figure 1: The mean age according to the gender.

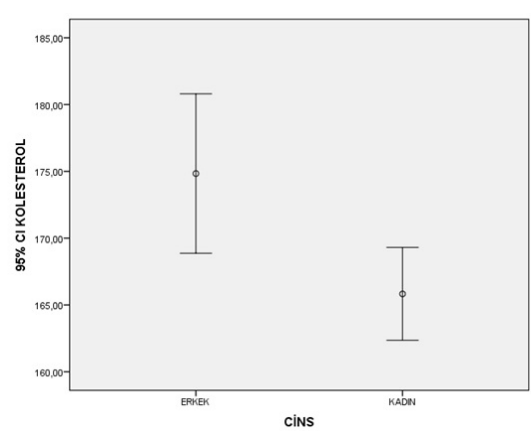

Figure 2: The mean cholesterol level according to the gender.

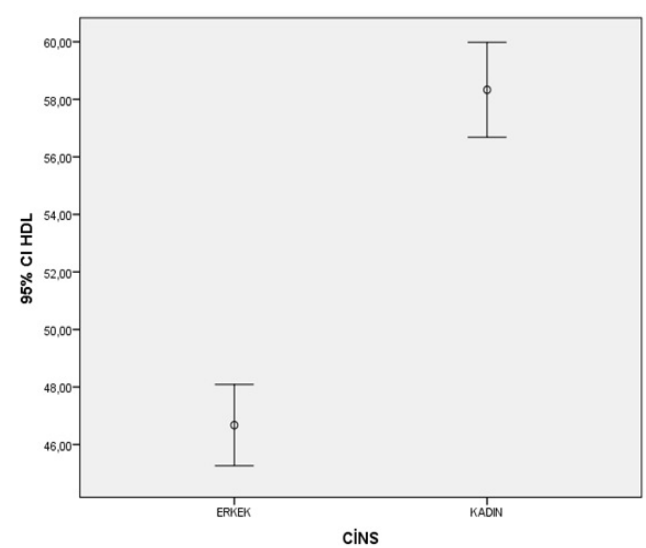

Figure 3: The mean triglyceride level according to the gender.

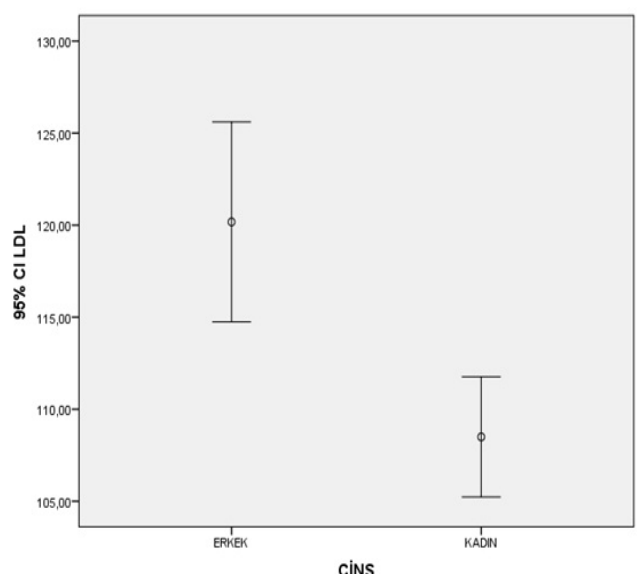

Figure 4: HDL cholesterol level according to the gender. 


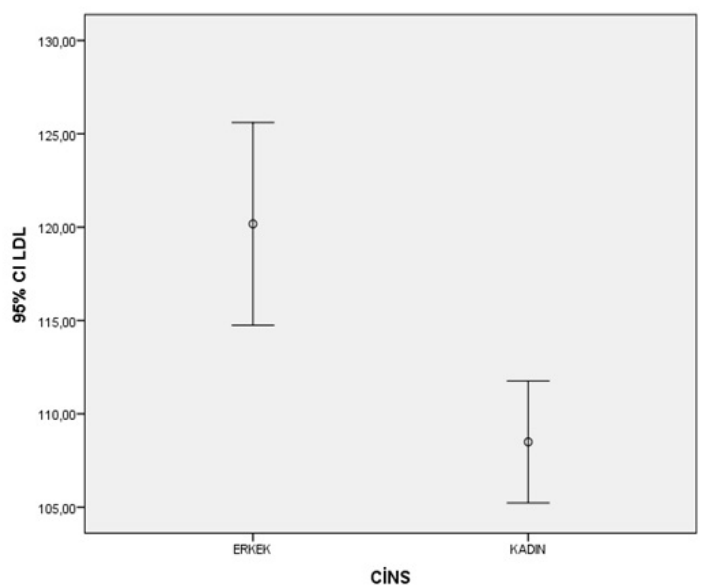

Figure 5: LDL cholesterol level according to the gender

\section{Conclusion}

In our study, total cholesterol, LDL, and triglyceride levels of male patients were significantly higher than the levels of female patients. However, HDL levels of male patients were significantly lower than the levels of female patients. According to the classification of the ATP III lipid parameters, total cholesterol, LDL and HDL triglyceride levels of both male and female patients were normal. These values can be decreased with the help of proper nutrition and exercise. It is believed that even lower values can lead to decrease CAD risk. However, genetic factors should also be considered. In our study, LDL levels of both groups were higher than the optimal levels in ATP III. There are young individuals in these groups and thus the number of hyperlipidemic subjects can increase in the future and CAD risk can also increase. Our findings may not represent the status of the entire community because of the limited number of subjects, exclusion of the young individuals, and being limited to one region of the country. Therefore, studies with higher numbers of patients can better show the general status in the community.

\section{References}

1. Kayaalp O (2002) Hipolipidemik Ilaçlar. Kayaalp O (ed.) Rasyonel Tedavi Yönünden Tibbi Farmakoloji. Hacettepe-Taş, Ankara, Turkey.

2. Kiliçarslan A, Öz GS (2012) Hiperlipidemiye Güncel Bakis. Iç hastaliklari dergisi 19: 1-8.

3. Harikumar K, Althaf SA, kumar BK, Ramunaik M, Suvarna CH (2013) A Review on Hyperlipidemic. International Journal of Novel Trends in Pharmaceutical Sciences 3: 59-71.

4. Zengin H (2012) Ateroskleroz patogenezi. Deneysel ve Klinik Tip Dergisi. Journal of Experimental and Clinical Medicine 29: 101-106.

5. Ermis C, Kiliçalp M, Tuzcu EM (2002) Koroner Ateroskleroz Tanisinda Damariçi ultrason. Turk Kardiyol Dern Ars 30: 254-264.
6. Lloyd-Jones D, Adams RJ, Brown TM, Carnethon M, Dai S, et al. (2010) Executive summary: heart disease and stroke statistics--2010 update: a report from the American Heart Association. Circulation 121: 948-954.

7. Ragbetli C (2009) HiperlipidemiVan Tip Dergisi 16: 43-47.

8. McGill HC Jr, Herderick EE, McMahan CA, Zieske AW, Malcolm GT, et al. (2002) Atherosclerosis in youth. Minerva Pediatr 54: 437-447.

9. [No authors listed] (1994) National Cholesterol Education Program. Second report of the Expert Panel on Detection, Evaluation, and Treatment of High Blood Cholesterol in Adults (Adult Treatment Panel II). Circulation 89: $1333-1445$

10. Ngoc TH, Ngoc QN, Van ATT, Phung NV (2008) Hypolipidemic Effect of Extracts from Abelmoschus esculentus L. (Malvaceae) on Tyloxapol-Induced Hyperlipidemia in Mice. Mahidol University Journal of Pharmaceutical Sciences 35: 42-46.

11. Hopkins PN, Heiss G, Ellison RC, Province MA, Pankow JS et al. (2003) Coronary artery disease risk in familial combined hyperlipidemia and familial hypertriglyceridemia: A case-control comparison from the National Heart, Lung, and Blood Institute Family Heart Study. Circulation 108: $519-523$

12. Ford ES, Giles WH, Dietz WH (2002) Prevalence of the metabolic syndrome among US adults: findings from the third national health and nutrition examination survey. JAMA 287: 356-359.

13. Erdogan AF (2007) Aile Hekimligi Poliklinigine Basvuran Hastalarda Hiperlipidemi Sikligi ve HDL Düzeyi ile Ilislkili Faktörler. Türk Aile Hek Derg 11: 107-112.

14. Alagoz G, Cevik Y, Kavalci C (2007) Gögüs Agrisi Sikayetiyle Acil Servise Basvuran Hastalarda Lipid Profili.

15. Kara S, Arslan B, Mergen H, Öngel K (2012) Aile Hkimligi Polikliniklerinde Kardiovasküler Risk Faktörleri nin Degerlendirilmesi. Tepecik Egit Hast Derg 22: 163-169.

16. AgaçhanB, Yilmaz H, Öztürk O, Ergen H, Isbir C (2005) Aterosklerozda Apolipoprotein e, Okside-ldl ve Lipid Profili Iliskisinin Arastirilmasi. FÜ Saglik B Dergisi 19: 193-197.

17. Koyama S, Saito Y, Yamanouchi H, Nagura H, Chida K, et al. (2003) [Marked decrease of intracranial atherosclerosis in contrast with unchanged coronary artery stenosis in Japan]. Nihon Ronen Igakkai Zasshi 40: $267-273$.

18. Rosenson RS (2005) Low HDL-C: a secondary target of dyslipidemia therapy. Am J Med 118: 1067-1077.

19. O’Loughlin J, Lauzon B, Paradis G, Hanley J, Lévy E, et al. (2004) Usefulness of the American Academy of Pediatrics recommendations for identifying youths with hypercholesterolemia. Pediatrics Jun 113: 1723-1727.

20. Misra A (2000) Risk factors for atherosclerosis in young individuals. J Cardiovasc Risk 7: 215-229.

21. American Academy of Pediatrics. Committee on Nutrition (1998) American Academy of Pediatrics. Committee on Nutrition. Cholesterol in childhood. Pediatrics 101: 141-147.

22. Garcia RE, Moodie DS (1989) Routine cholesterol surveillance in childhood. Pediatrics 84: 751-755. 